\title{
PENGARUH PELATIHAN TERHADAP KINERJA KARYAWAN PADA PT. ELECTRONIC CITY
}

\author{
Endang Susilo Wardani ${ }^{1 *}$ \\ ${ }^{1)}$ Universitas Pamulang \\ *Penulis Korespondensi: dosen01645@unpam.ac.id
}

\begin{abstract}
Karyawan professional seolah menjadi dambaan bagi setiap perusahaan, dimana karyawan adalah faktor yang berperan penting dalam perusahaan. Melalui pelatihan yang dilakukan perusahaan diharapkan karyawan dapat memenuhi standar ideal yang ditentukan oleh perusahaan dengan potensi yang dimiliki seorang karyawan baik keterampilan, pengetahuan maupun sikap yang dapat ditingkatkan pada setiap pelatihan. Penelitian ini bertujuan untuk mengetahui pengaruh pelatihan terhadap kinerja karyawan pada PT. Electronick City Cabang BSD Tangerang. Metode yang digunakan adalah explanatory research dengan sampel sebanyak 52 responden. Teknik analisis menggunakan analisis statistik dengan pengujian regresi, korelasi, determinasi dan uji hipotesis.
\end{abstract}

Keywords: Pelatihan, Kinerja Karyawan. 


\section{PENDAHULUAN}

Sumber daya manusia adalah faktor yang paling menentukan dalam pencapaian tujuan perusahaan. Karena sumber daya manusia termasuk unsur dari kekuatan daya saing negara, untuk itu sumber daya manusia dituntut menjadi unggul dan professional dalam kerjanya demi kemajuan dan pencapaian tujuan perusahaan di Indonesia khususnya agar bisa bersaing dalam era globalisasi ini.

Karyawan professional seolah menjadi dambaan bagi setiap perusahaan, dimana karyawan adalah faktor yang berperan penting dalam perusahaan. Melalui pelatihan yang dilakukan perusahaan diharapkan karyawan dapat memenuhi standar ideal yang ditentukan oleh perusahaan dengan potensi yang dimiliki seorang karyawan baik keterampilan, pengetahuan maupun sikap yang dapat ditingkatkan pada setiap pelatihan.

Apa jadinya jika suatu perusahaan menerima karyawan tanpa mengadakan training (pelatihan).Pelatihan sangat dibutuhkan untuk karyawan baru ataupun karyawan yang naik jabatan, karena pada dasarnya karyawan tersebut memasuki lingkungan kerja yang lebih baik.Setiap aktivitas yang dilakukan seseorang pasti memiliki suatu faktor yang mendorong pada aktivitas tersebut, oleh karena itu faktor pendorong diri seorang manusia untuk melakukan aktivitas tertentu pada umumnya adalah kebutuhan serta keinginan dari orang tersebut.

Menurut Kaswan (2016) pelatihan adalah proses meningkatakan pengetahuan dan keterampilan karyawan meliputi pengubahan sikap sehingga karyawan dapat melakukan pekerjaan yang lebih efektif. Seseorang yang bekerja akan memiliki output berupa unjuk kerja atau produk kerja yang ditunjukan sebagai manifestasi hasil pekerjaannya. Kinerja seseorang merupakan hal yang kompleks dan terpadu, yang keberhasilannya dipengaruhi oleh berbagai faktor, baik faktor internal maupun faktor eksternal. Faktor internal yang mempengaruhi kinerja seseorang antara lain adalah bakat, minat, motivasi dan kesehatan. Faktor eksternal yang mempengaruhi kinerja seseorang antara lain adalah lingkungan, sarana dan manajemen.

Menurut Hasibuan (2014) menjelaskan bahwa manajemen adalahilmu dan seni mengatur proses pemanfaatan sumber daya manusia dan sumber-sumber lainnya secara efektif dan efesien untuk mencapai suatu tujuan tertentu. PT. Electronic City Cabang BSD Tangerang adalah salah satu pelopor perusahaan ritail produk elektronik modern di Indonesia yang mengeluarkan produk-produk elektronik terbaik kepada para pelanggan, serta memberikan pelayanan yang baik secara langsung dan juga harus mampu memberikan kinerja yang baik kepada pelanggan. Dalam hal ini PT. Electronic City Cabang BSD Tangerang juga telah memberikan pelatihan kepada para karyawannya demi meningkatkan kinerja, namun pelatihanyang diberikan belum maksimal.

Berikut adalah tabel data pelatihan pada PT. Electronic City Cabang BSD Tangerang:

Tabel 1. Data Pelatihan PT. Electronic City Tahun 2015-2019

\begin{tabular}{|l|l|l|l|l|l|}
\hline \multirow{2}{*}{ Tahun } & \multirow{2}{*}{$\begin{array}{l}\text { Jumlah } \\
\end{array}$} & Karyawan & \multicolumn{2}{|c|}{ Trained } & \multicolumn{2}{l|}{ Un-trained } \\
\cline { 3 - 6 } & Orang & $\%$ & Orang & $\%$ \\
\hline 2015 & 50 & 22 & $44.0 \%$ & 28 & $56.0 \%$ \\
\hline 2016 & 50 & 24 & $48.0 \%$ & 26 & $52.0 \%$ \\
\hline 2017 & 52 & 18 & $34.6 \%$ & 34 & $65.4 \%$ \\
\hline 2018 & 52 & 16 & $30.8 \%$ & 36 & $69.2 \%$ \\
\hline 2019 & 52 & 12 & $23.1 \%$ & 40 & $76.9 \%$ \\
\hline
\end{tabular}

Sumber: Data primer diolah, 2019

Dari data pelatihan yang diperoleh, 52 karyawan yang ada tidak semua mendapatkan pelatihan untuk unit kerja masing-masing, dan tidak semua karyawan semangat dalam mengikuti pelatihan yang diberikan. Dalam waktu satu tahun dapat dipresentasikan kurang lebih 50\% yang mendapatkan pelatihan. Pengadaan pelatihan ini ditujukan agar karyawan memiliki kemampuan dasar dalam bidang ritail dan memiliki semangat kerja yang tinggi terhadap kinerjanya.Namun sampai saat ini masih banyak kendala-kendala yang dihadapi dalam memberikan pelatihan (training) bagi karyawan. Hal ini dikarenakan belum adanya sarana dan prasarana serta fasilitas, penunjang pelatihan yang masih kurang, belum adanya indikator pengukur kinerja karyawan yang maksimal, serta sistem manajemen yang belum stabil, dan masih kurangnya semangat karyawan dalam menjalankan pelatihan (training) yang diberikan.

Oleh karena itu dengan adanya pelatihan yang diberikan kepada karyawan diharapkan dapat meningkatkan pengetahuan dan keterampilan karyawan yang dapat menunjang kinerja karyawan dalam melaksanakan pekerjaannya. Perusahaan dapat 
berjalan sesuai dengan yang diinginkan karena dilakukan oleh sumber daya manusia yang handal dan diperkuat dengan sistem manajemen yang bagus dan terampil.Peran manajemen sumber daya manusia sangat menentukan bagi terwujudnya organisasi yang maju, tetapi untuk memimpin manusia merupakan hal yang cukup sulit.Karyawan selain diharapkan mampu, cakap dan terampil juga hendak berkemampuan dan mempunyai kesungguhan untuk bekerja efektif dan efisien.

Menurut Mangkunegara (2015) mengemukakan bahwa kinerja adalah hasil kerja secara kualitas dankuantitas yang dicapai oleh seorang pegawai dalam melaksanakan tugasnya sesuai tanggung jawab yang diberikan kepadanya. Untuk mencapai kinerja yang diharapkan dalam suatu organisasi atau perusahaan, para pegawai harus mendapatkan program pelatihan yang memadai untuk jabatannya sehingga karyawan terampil dalam melaksanakan pekerjaannya. Untuk meningkatkan mutu atau kinerja pegawai melalui pelatihan harus dipersiapkan dengan baik untuk mencapai hasil yang memuaskan. Peningkatan mutu atau kinerja harus diarahkan untuk mempertinggi keterampilan dan kecakapan pegawai dalam melaksanakan atau melakukan tugasnya. Masih kurangnya materi dan metode yang di berikan perusahaan terhadap karyawan serta kualifikasi peserta dalam pelatihan masih kurang yang mengakibatkan rendahnya kualifikasi setiap karyawan PT. Electronic City Cabang BSD Tangerang juga sangat memperhatikan tentang pencapaian hasil kerja dari masing-masing karyawan. Yang mengakibatkan belum optimanya kualitas yang di berikan karywan sehingga perusah memberikan pelatihan Kegiatan ini dilakukan manajemen untuk tujuan memonitoring setiap karyawan yang memiliki semangat dan yang tidak semangat dalam bekerja yang dapat dilihat dari pencapaian target setiap tahunnya.

Berikut target pencapaian karyawan PT. Electronic City Cabang BSD Tangerang periode tahun 2014 - 2016 dapat dilihat pada tabel 2 dibawah ini :
Tabel 2. Target dan Pencapaian Karyawan PT. Electronic City Cabang BSD Tangerang, Periode 2014 - 2016

\begin{tabular}{|l|l|l|l|}
\hline Tahun & $\begin{array}{l}\text { Target } \\
\text { Penjualan (Rp) }\end{array}$ & $\begin{array}{l}\text { Realisasi } \\
\text { Penjualan }(\mathrm{Rp})\end{array}$ & $\begin{array}{l}\text { Pencapaian } \\
(\%)\end{array}$ \\
\hline 2017 & $12,632,000,000$ & $10,976,000,000$ & $86,8 \%$ \\
\hline 2018 & $11,164,000,000$ & $8,760,000,000$ & $78,4 \%$ \\
\hline 2019 & $10,697,000,000$ & $6,589,000,000$ & $61,6 \%$ \\
\hline
\end{tabular}

Sumber : Data primer diolah, 2019

Berdasarkan tabel di atas dapat dilihat tingkat semangat karyawan PT. Electronic City Cabang BSD Tangerang masih belum stabil. Hal ini dikarenakan mesih belum mencapai terget yang diharapkan pada setiap tahunnya. Pada tahun 2017 pencapain target 86,8\% dari target penjualan $\mathrm{Rp} 12,632,000,000$. Pada tahun 2018 pencapain target $78,4 \%$ dari target penjualan Rp 11,164,000,000. Pada tahun 2019 pencapain target hanya sebesar $61,6 \%$ dari target penjualan Rp 10,697,000,000.

Pentingnya kinerja pada PT. Electronic City Cabang BSD Tangerang dalam motivasi karyawan sebagai keadaan dalam pribadi seseorang yang mendorong keinginan individu untuk melaksanakan kegiatan-kegiatan untuk mencapai tujuan. Pemberian motivasi juga berarti memberikan kesempatan kepada karyawan untuk mampu mengembangkan kemampuan dan merupakan dorongan semaksimal mungkin karyawan untuk meningkatkan hasil kinerja yang lebih baik dan merupakan dorongan untuk karyawan berprestasi.

PT. Electronic City Cabang BSD Tangerang menyadari bahwa untuk tercapainya suatu perusahaan perlu adanya hubungan yang harmonis antara perusahaan dan karyawan dengan adanya saling menghargai dan mempercayai dengan penuh rasa tanggung jawab dalam melaksanakan tugasnya. Peraturan perusahaan digunakan sebagai pedoman hubungan kerja bagi perusahaan dan seluruh karyawan dalam melaksanakan tugas dan kewajiban masing-masing demi kelangsungan perusahaan dan peningkatan kesejahteraan karyawan.

Dengan adanya pelatihan (training) yang diberikan kepada setiap karyawan pada PT. Electronic City Cabang BSD Tangerang diharapkan para karyawand apat meningkatkan keterampilan, kemampuan dan pengetahuan dalam menyelesaikan pekerjaan di dalam bidang ritail produk elektronik seperti memasarkan produk danm encapai target. Karyawan diharapkan memiliki sikap yang 
positif terhadap lingkungan pekerjaan seperti sikap terhadap sesama rekan kerja, atasan, dan pekerjaan. Sehingga dengan adanya pelatihan yang diberikan dapat mendorong peningkatan kinerja karyawan.

Berdasarkan latar belakang diatas merupakan permasalahan bagi PT. Electronic City Cabang BSD Tangerang untuk memberikan pelatihan bagi karyawan guna dapat melaksanakan pekerjaan dengan baik serta meningkatkan kinerja karyawan secara maksimal. Hal ini mendorong penulis untuk meneliti sejauh mana pengaruhnya pelatihan, motivasi terhadap kinerja karyawan pada PT. Electronic City Cabang BSD Tangerang.

\section{METODE PENELITIAN}

Populasi dalam penelitian ini berjumlah 52 responden PT. Electronick City Cabang BSD Tangerang Teknik pengambilan sampling dalam penelitian ini adalah sampel jenuh, dimana semua anggota populasi dijadikan sebagai sampel. Dengan demikian sampel dalam penelitian ini sampel yang digunakan berjumlah 52 responden. Jenis Penelitian yang dipakai adalah asosiatif, dimana tujuannya adalah untuk mengetahui atau mencari keterhubungan antara variabel independen terhadap variabel dependennya. Dalam menganalisis data digunakan uji validitas, uji reliabilitas, analisis regresi linier sederhana, analisis koefisien korelasi, analisis koefisien determinasi dan pengujian hipotesis.

\section{HASIL DAN PEMBAHASAN}

Analisis Deskriptif

Pada pengujian ini digunakan untuk mengetahui skor minimum dan maksimum skor tertinggi, ratting score dan standar deviasi dari masing-masing variabel. Adapun hasilnya sebagai berikut:

Tabel 3. Hasil Analisis Descriptive Statistics Descriptive Statistics

\begin{tabular}{|c|c|c|c|c|c|}
\hline & $\mathrm{N}$ & Minimum & a Maximum & Mean & $\begin{array}{l}\text { Std. } \\
\text { Deviation }\end{array}$ \\
\hline$\overline{\text { Pelatihan (X1) }}$ & 52 & 29 & 47 & 37.87 & 4.765 \\
\hline $\begin{array}{l}\text { Kinerja Karyawans } \\
(\mathrm{Y})\end{array}$ & 152 & 29 & 49 & 38.25 & 3.980 \\
\hline Valid N (listwise) & 52 & & & & \\
\hline
\end{tabular}

Pelatihan diperoleh varians minimum sebesar 29 dan varians maximum 47 dengan ratting score sebesar 3,787 dengan standar deviasi 4,765 . Skor ini termasuk pada rentang sakala 3,40 - 4,19 dengan kriteria baik atau setuju.

Kinerja karyawan diperoleh varians minimum sebesar 29 dan varians maximum 49 dengan ratting score sebesar 3,825 dengan standar deviasi 3,980. Skor ini termasuk pada rentang sakala 3,40 - 4,19 dengan kriteria baik atau setuju.

\section{Analisis Verifikatif.}

Pada analisis ini dimaksudkan untuk mengetahui pengaruh variabel independen terhadap variabel dependen. Adapun hasil pengujian sebagai berikut:

Analisis Regresi Linier Sederhana

Uji regresi ini dimaksudkan untuk mengetahui perubahan variabel dependen jika variabel independen mengalami perubahan. Adapun hasil pengujiannya sebagai berikut:

Tabel 4. Hasil Pengujian Regresi Linier Sederhana

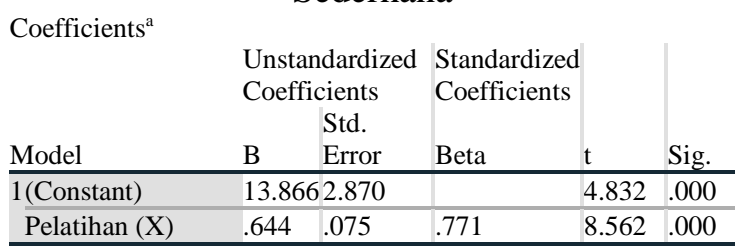

Berdasarkan hasil pengujian pada tabel di atas, diperoleh persamaan regresi $\mathrm{Y}=13,866+$ 0,644X. Dari persamaan tersebut dijelaskan sebagai berikut:

Konstanta sebesar 13,866 diartikan jika pelatihan tidak ada, maka telah terdapat nilai kinerja karyawan sebesar 13,866 point.

Koefisien regresi pelatihan sebesar 0,644 , angka ini positif artinya setiap ada peningkatan pelatihan sebesar 0,644 point maka kinerja karyawan juga akan mengalami peningkatan sebesar 0,644 point.

Analisis Koefisien Korelasi

Analisis koefisien korelasi dimaksudkan untuk mengetahui tingkat kekuatan hubungan dari variabel independen terhadap variabel dependen. Adapun hasil pengujian sebagai berikut:

Tabel 5. Hasil Pengujian Koefisien Korelasi Pelatihan Terhadap Kinerja Karyawan.

\begin{tabular}{|c|c|c|c|}
\hline \multicolumn{4}{|l|}{ Correlations $^{\mathrm{b}}$} \\
\hline & & $\begin{array}{l}\text { Pelatihan } \\
\text { (X1) }\end{array}$ & $\begin{array}{l}\text { Kinerja } \\
\text { Karyawan (Y) }\end{array}$ \\
\hline \multirow[t]{2}{*}{$\overline{\text { Pelatihan (X1) }}$} & $\begin{array}{l}\text { Pearson } \\
\text { Correlation }\end{array}$ & 1 & $.771^{* *}$ \\
\hline & Sig. (2-tailed) & & .000 \\
\hline \multicolumn{2}{|c|}{ Kinerja KaryawanPearson } & $.771^{* *}$ & 1 \\
\hline$(\mathrm{Y})$ & Sig. (2-tailed) & .000 & \\
\hline
\end{tabular}


Berdasarkan hasil pengujian diperoleh nilai korelasi sebesar 0,771 artinya pelatihan memiliki hubungan yang kuat terhadap kinerja karyawan.

\section{Analisis Koefisien Determinasi}

Analisis koefisien determinasi dimaksudkan untuk mengetahui besarnya persentase pengaruh dari variabel independen terhadap variabel dependen. Adapun hasil pengujian sebagai berikut:

Tabel 6. Hasil Pengujian Koefisien

Determinasi Pelatihan Terhadap Kinerja Karyawan.

\begin{tabular}{|c|c|c|c|c|}
\hline & Summ & & & \\
\hline Model & & R Square & $\begin{array}{l}\text { Adjusted } \\
\text { Square }\end{array}$ & $\begin{array}{l}\text { R Std. Error of the } \\
\text { Estimate }\end{array}$ \\
\hline 1 & $.771^{\mathrm{a}}$ & .595 & .586 & 2.559 \\
\hline
\end{tabular}

Berdasarkan hasil pengujian diperoleh nilai determinasi sebesar 0,595 artinya pelatihan memiliki kontribusi pengaruh sebesar 59,5\% terhadap kinerja karyawan, sedangkan sisanya sebesar 40,5\% dipengaruhi oleh faktor lain yang tidak dilakukan penelitian.

\section{Uji Hipotesis}

Pengujian hipotesis dengan uji $\mathrm{t}$ digunakan untuk mengetahui hipotesis mana yang diterima.

Rumusan hipotesis: Terdapat pengaruh yang signifikan antara pelatihan terhadap kinerja karyawan.

\section{Tabel 7. Hasil Uji Hipotesis Pelatihan} Terhadap Kinerja Karyawan. Coefficients $^{\mathrm{a}}$

\begin{tabular}{lllll|r} 
& \multicolumn{2}{l}{$\begin{array}{l}\text { Unstandardized } \\
\text { Coefficients } \\
\text { Model }\end{array}$} & $\begin{array}{l}\text { Standardized } \\
\text { Coefficients }\end{array}$ & & \\
& B & Error & Beta & t & Sig. \\
\hline 1 (Constant) & 13.8662 .870 & & 4.832 .000 \\
\hline Pelatihan $(\mathrm{X})$ & .644 & .075 & .771 & 8.562 .000 \\
\hline
\end{tabular}

Berdasarkan hasil pengujian pada tabel di atas, diperoleh nilai $\mathrm{t}$ hitung $>\mathrm{t}$ tabel atau (8,562 > 2,009), dengan demikian hipotesis yang diajukan bahwa terdapat pengaruh yang signifikan atara pelatihan terhadap kinerja karyawan diterima.

\section{Pembahasan Hasil Penelitian}

Berdasarkan jawaban responden, variabel pelatihan diperoleh ratting score sebesar 3,787 berada di rentang skala 3,40 - 4,19 dengan kriteria baik atau setuju. Kondisi Jawaban Responden Variabel Kinerja Karyawan. Berdasarkan jawaban responden, variabel kinerja karyawan diperoleh ratting score sebesar 3,825 berada di rentang skala 3,40 4,19 dengan kriteria baik atau setuju. Pengaruh Pelatihan Terhadap Kinerja Karyawan

Pelatihan berpengaruh signifikan terhadap kinerja karyawan dengan persamaan regresi $\mathrm{Y}$ $=13,866+0,644 \mathrm{X}$, nilai korelasi sebesar 0,771 atau memiliki hubungan yang kuat dengan kontribusi pengaruh sebesar 59,5\%. Pengujian hipotesis diperoleh nilai $t$ hitung $>\mathrm{t}$ tabel atau $(8,562>2,009)$. Dengan demikian hipotesis yang diajukan bahwa terdapat berpengaruh signifikan antara pelatihan terhadap kinerja karyawan diterima. Penelitian ini sesuai dengan penelitian yang dilakukan oleh Denok, et.al. yang menyatakan Lingkungan Kerja berpengaruh signifikan terhadap kinerja karyawan dengan hubungan yang kuat dengan kontribusi pengaruh sebesar $62,2 \%$.

\section{KESIMPULAN DAN SARAN}

\section{Kesimpulan}

Variabel pelatihan diperoleh ratting score sebesar 3,787 berada di rentang skala 3,40 4,19 dengan kriteria baik atau setuju. Variabel kinerja karyawan diperoleh ratting score sebesar 3,825 berada di rentang skala 3,40 4,19 dengan kriteria baik atau setuju. Pelatihan berpengaruh signifikan terhadap kinerja karyawan dengan persamaan regresi $\mathrm{Y}=$ $13,866+0,644 X$, nilai korelasi sebesar 0,771 atau kuat dan kontribusi pengaruh sebesar $59,5 \%$ sedangkan sisanya sebesar $40,5 \%$ dipengaruhi faktor lain. Uji hipotesis diperoleh nilai t hitung $>\mathrm{t}$ tabel atau $(8,562>2,009)$.

\section{Saran}

Berdasarkan hasil penelitian, maka penulis memiliki saran-saran yang terkait dengan pelatihan dan kinerja karyawan pada PT. Electronic City Cabang BSD Tangerang, yaitu sebagai berikut : Disarankan karyawan pada PT. Electronic City Cabang BSD Tangerang seharusnya mampu bekerja sama dengan baik dalam melakukan pekerjaan. Disarankan karyawan pada PT. Electronic City Cabang BSD Tangerang seharusnya memenuhi persyaratan standar pekerjaan. Disarankan karyawan pada PT. Electronic City Cabang BSD Tangerang seharusnya siap dalam menghadapi berbagai resiko kerja. 


\section{REFERENSI}

Effendy, A., \& Sunarsi, D. (2020). Persepsi

Mahasiswa Terhadap Kemampuan

Dalam Mendirikan UMKM Dan

Efektivitas Promosi Melalui Online Di

Kota Tangerang Selatan. Jurnal Ilmiah

MEA (Manajemen, Ekonomi, \&

Akuntansi), 4(3), 702-714.

https://doi.org/10.31955/mea.vo

14.iss3.pp702-714

Jasmani, J., \& Paeno, P. (2019). The Effect of Leadership and Competence on Lecturer Performance and Its Implications on Student Learning Motivation at Pamulang University International Journal of Advances in Social and Economics, 1(4).

Jasmani, J., \& Sunarsi, D. (2020). The Influence of Product Mix, Promotion Mix and Brand Image on Consumer Purchasing Decisions of Sari Roti Products in South Tangerang. PINISI Discretion Review, l(1), 165-174.

Kaswan. Pelatihandan Pengembangan. (2016) Grahallmu, Yogyakarta.

Mangkunegara, A.A. Anwar Prabu. "Manajemen Sumber Daya Manusia Perusahaan". $2015 . \quad$ PT. Remaja Rosda Karya, Bandung,

Pardede, Ratlan dan Marunung, Reinhard. Analisis Jalur (Path Analysis) Teori dan Aplikasi dalam Riset Bisnis. 2014. PT. Renika Cipta, Jakarta.

Purwanto, A., Sunarsi, D., \& Wijoyo, H. (2020). Penerapan Perluasan Arti Perbuatan Melanggar Hukum Dalam Pelaksanaan UU 29 Tahun 2004 (Studi Kasus Putusan No. 625/PDT. G/2014/PN JKT. BRT). TIN Terapan Informatika Nusantara, $\quad$ 1(2), 99-103.

Rivai, Veitzhal. Manajemen Sumber Daya Manusia untuk Perusahaan. 2014. Raja Grafindo Persada, Jakarta.

Sedarmayanti. Sumber Daya Manusia danProduktivitas. 2013. CV.

MajuMundur, Bandung.

Siregar, Syofian. Metode Penelitian Kuantitatif. 2014. Kencana. Jakarta.
Sofyandi, Herman. "Manajemen Sumber Daya Manusia". 2010. Edisi Pertama. Cetakan Pertama. Grahallmu, Yogyakarta.

Sugiyono. "Metode Penelitian (Pendekatan Kuantitatif, Kualitatifdan $R$ \& D)". Alfabeta, Bandung, 2016.

Sunarsi, D. (2018). Buku Ajar: Seminar Perencanaan Sumber Daya Manusia. Tangerang Selatan: Asmoro Mediatama

Sunarsi, D. (2018). Pengembangan Sumber Daya Manusia Strategik \& Karakterisrik Sistem Pendukungnya : Sebuah Tinjauan. Jurnal Ilmiah MEA (Manajemen, Ekonomi, \& Akuntansi), 2(3), 178 - 194. https://doi.org/10.31955/mea.vo 12.iss3.pp178 - 194

Sunarsi, D., Wijoyo, H., Prasada, D., \& Andi, D. (2020). Pengaruh Lingkungan Kerja Terhadap Kinerja Karyawan Pada PT. Mentari Persada Di Jakarta. In Seminar Nasional Manajemen, Ekonomi, Akuntansi (Vol. 5, No. 1, pp. 117-123).

Supranto J dan Lima krisna, Perilaku Konsumen dan Strategi Pemasaran Untuk Memenangkan Persaingan Bisnis. Mitra Wacana Media. Jakarta, 2013. Sutrisno, Edy. "Manajemen Sumber Daya Manusia". 2012. Kencana, Jakarta.

Sutrisno, Edy. "Manajemen Sumber Daya Manusia". 2016. Prenada Media Group, Jakarta.

Terry, George R. Dasar-Dasar Manajemen. 2010. Cetakan Kesebelas. PT Bumi Aksar Jakarta. 